\title{
MELD-Na score and postoperative complications in hernia repair
}

\author{
S. Yasri ${ }^{1} \cdot$ V. Wiwanitkit ${ }^{2}$
}

Received: 21 November 2018 / Accepted: 9 January 2019 / Published online: 22 January 2019

○) Springer-Verlag France SAS, part of Springer Nature 2019

Dear Editor,

We read the publication on "Model for End-Stage Liver Disease Sodium (MELD-Na) score associated with postoperative complications in hernia repair in non-cirrhotic patients" with a great interest [1]. Schlosser et al. concluded that "MELD-Na score is independently associated with postoperative complications in ventral hernia repair [1]". In fact, the important problem for using the mentioned scope in clinical practice is the variability of the score due to the basic primary parameters of the score derived from different laboratories [2]. In addition, it is also observed that the MELD-Na score was greatly affected by international normalised ratio (INR) [3]. Hence, the use of the score has to be carefully interpreted in cases with anticoagulant treatment [3].

\section{Compliance with ethical standards}

Conflict of interest Authors declare that they have no conflict of interest.

Ethical approval Approval from the institutional review board was not required for this study.
Human and animal rights This article does not contain any studies directly involving human participants, as it is a review of data already collected in a hernia database.

Informed consent For this type of study, formal consent was not required.

\section{References}

1. Schlosser KA, Kao AM, Zhang Y, Prasad T, Kasten KR, Davis BR, Heniford BT, Colavita PD (2018) MELD-Na score associated with postoperative complications in hernia repair in non-cirrhotic patients. Hernia. https://doi.org/10.1007/s10029-018-1849-2 (Epub ahead of print)

2. Xiol X, Gines P, Castells L, Twose J, Ribalta A, Fuentes-Arderiu X, Rodriguez S, Castellote J, Navasa M, Deulofeu R (2009) Clinically relevant differences in the model for end-stage liver disease and model for end-stage liver disease-sodium scores determined at three university-based laboratories of the same area. Liver Transpl 15(3):300-305

3. Lisman T, van Leeuwen Y, Adelmeijer J, Pereboom IT, Haagsma EB, van den Berg AP, Porte RJ (2008) Interlaboratory variability in assessment of the model of end-stage liver disease score. Liver Int 28(10):1344-1351

Publisher's Note Springer Nature remains neutral with regard to jurisdictional claims in published maps and institutional affiliations.

\section{S. Yasri}

sorayasri@outlook.co.th

KMT Primary Care Center, Bangkok, Thailand

2 Dr. DY Patil University, Pune, India 